\title{
Changes in epilithic diatom assemblages in a Mediterranean high mountain lake (Laguna de La Caldera, Sierra Nevada, Spain) after a period of drought
}

\author{
Pedro M. SÁNCHEZ-CASTILLO*, J. Eduardo LINARES-CUESTA ${ }^{1)}$ and D. FERNÁNDEZ-MORENO \\ Departamento de Botánica, Facultad de Ciencias, Universidad de Granada, 18071 GRANADA, Spain \\ ${ }^{1)}$ Herbario de la Universidad de Granada, c/ Rector López Argüeta 8, 18071 GRANADA, Spain \\ *e-mail corresponding author: psanchez@ugr.es
}

\begin{abstract}
The epilithic diatom assemblages studied in the high mountain lake "La Caldera" (Granada, Spain) from 1996 to 1998 went through two clearly different stages. The initial one, in 1996, corresponded to the reflooding of the basin after a severe drought and was composed mainly of the colonising species Fragilaria rumpens, together with a lesser presence of Nitzschia sublinearis and Hantzschia amphioxys. The predominant presence of $\mathrm{F}$. rumpens at the end of the summer of 2006 coincided with low species diversity (values of Shannon and Wiener Index: 0.3-0.6). During the following two years another assemblage established itself, dominated by Achnanthidium minutissimum, which is considered to be more stable and widespread among the lakes of the Sierra Nevada. The most notable subdominant species (less than $20 \%$ of relative abundance) in this assemblage were: Encyonema minutum, Encyonopsis microcephala and Navicula cryptocephala. The diversity values during this second period were much higher than in the first: 1.0-2.2. Nutrient concentrations were measured separately in the limnetic (epilimnetic) and benthic (epilithic) environments. These abiotic parameters show that the dynamics of ammonia and silica were much the same in both, showing a gradual decrease from the beginning to the end of the study period. Epilimnetic phosphorus followed a similar pattern to ammonia and silica. In the epilithon, nitrates and phosphates increased during the first year, only to descend notably during the second. The effect of other environmental parameters such as temperature and the preceding drought on the dynamics of the diatom assemblage are discussed. Ratio DIN:SRP let us test the different degrees of phosphorus limitation in epilithon and epilimnion environments; our results suggest that phosphorus limitation of primary production in high mountain lakes is much more severe in the limnetic environment that it is in the epilithon.
\end{abstract}

Key words: diatoms, epilithon, oligotrophic lakes, nutrients, Sierra Nevada, Spain

\section{INTRODUCTION}

Studies of epilithic algal assemblages in lacustrine systems are scarce and somewhat piecemeal compared to studies in phytoplanktonic assemblages. The reason for this paucity might lie in the considerable methodological and taxonomic difficulties involved in studying the different groups of algae which make up epilithic assemblages, to such an extent that each community is quite often treated as a separate example of taxocoenosis. Diatoms are one group of organisms that have provided considerable information about these assemblages (Whitmore 1989; Dixit et al. 1991, 1993; Beyens \& Vijver 2000; Lim et al. 2001); however, there is still little overall understanding about the environmental conditions which control their growth, the processes of substitution involved in their long-term successions and the patterns of diversity found in different assemblages. Most recent research into diatom assemblages has been made with regards to their importance in palaeolimnology and their precision as bioindicators to changes in ecosystems, either natural or anthropic (Stoermer \& Smol 2000).

In lakes, epilithic assemblages constitute a very important interface between the rock substrate and the overlying water layer. The real significance of these algal communities with regard to the balance of nutrients in the water is not yet well understood but there is evidence to suggest that they may play a key role in the biology of oligotrophic high mountain lakes. A whole series of processes affect the thin epilithic layer, such as the sedimentation of planktonic organisms, the excretions of zooplankton and benthic fauna and the mineralization of organic remains. Epilithic species are the prime receptors of recycled inorganic nutrients (Loeb et al. 1983). The interactions between epiphytic assemblages and their substrates are quite well documented, and it has been observed that algae provide up to $60 \%$ of the phosphorus epilithic species consume (Wetzel 1990). In a similar manner, epilithic assemblages may obtain silica and other nutrients from the rocky substrate upon which they live (Douglas \& Smol 1995), although relative quantities have yet to be determined. Jones \& Juggins (1995) suggest that although the availability of benthic nutrients may differ from the water column, a correlation exists between limnetic and benthic nutrients in Antarctic lakes.

The relationships between epilithic assemblages and the physico-chemical characteristics of the water published to date tend to be based upon parameters measured in the epilimnion and therefore related primarily to plankton communities. Very few papers (Jones \& 
Juggins 1995) rely on the chemical analyses of the rockwater interface to assess changes in assemblage structures, most of them attempt to explain the dynamics of the epilithic community on the basis of the physicochemical characteristics of the epilimnetic environment.

The main aim of our work was to study the structural changes in the diatom assemblage in a high mountain lake, measured both in terms of diversity and succession. We also analysed the interstitial water found between the microstructures of the epilithon so as to be able to establish a closer relationship between the epilithic assemblages and the recycling of nutrients which, as has already been suggested by Douglas \& Smol (1995), may occur within the layers of these algal communities.

\section{METHODS}

\subsection{Site description}

Laguna de La Caldera is a high mountain lake of glacial origin at $3050 \mathrm{~m}$ a.s.l. in the Sierra Nevada in southern Spain. The lake has a shallow sided basin and remains frozen from November to May, approximately. It had a maximum depth of $15 \mathrm{~m}$ during the study period, although this varied considerably according to local climatic conditions. The lake contains relatively few phytoplanktonic organisms (Sánchez-Castillo et al. 1989; Carrillo et al. 1995; Medina-Sánchez et al. 1999), and so the water is generally very clear and the light easily reaches the bottom, thus encouraging the growth of benthic assemblages. The lake bed is mainly composed of micaschist rocks, upon which the epilithic communities described in this study develop.

Between 1985 and 1995 La Caldera suffered the consequences of a prolonged drought and its depth decreased from the normal $10-12 \mathrm{~m}$ to only $1.5 \mathrm{~m}$ in the summer of 1995. In 1996 the level of the water returned to flood the top edge of the lake. This situation has allowed us to study the process of colonization of a substrate that submerged in a given known moment (year 1996, when the period of sampling of this work begins).The samples taken during the summer of 1996, when the lake had returned to a depth of $15 \mathrm{~m}$ (Fig. 1), thus corresponded to communities growing upon substrates that had been resubmerged after having been emerged for several years. From 1997 onwards however the lake maintained its depth and the samples collected during these years could be considered as being more mature epilithic assemblages.

\subsection{Sampling methods}

The samples were taken during ice-free periods from the end of June to the beginning of October (19961998). Samples were taken three times each year, corresponding to the beginning, middle and end of the lake's ice-free phase. Three stones were sampled at each of the six equidistant points situated around the edge of the lake, at a depth of $0.5 \mathrm{~m}$. Total epilithic area sampled from the three stones was estimated at $150 \mathrm{~cm}^{2}$. The film covering each of the three stones was scraped off and the resulting residue was put together to form a single sample from which aliquots were taken for the various analyses. The data referred to in the Results section correspond to the mean values from the six points sampled around the edge of the lake.

\subsection{Chemical analyses}

Chemical analyses carried out at the rock-water interface were performed on the water that was separated from the epilithic biofilm scrapped off the rocks. To

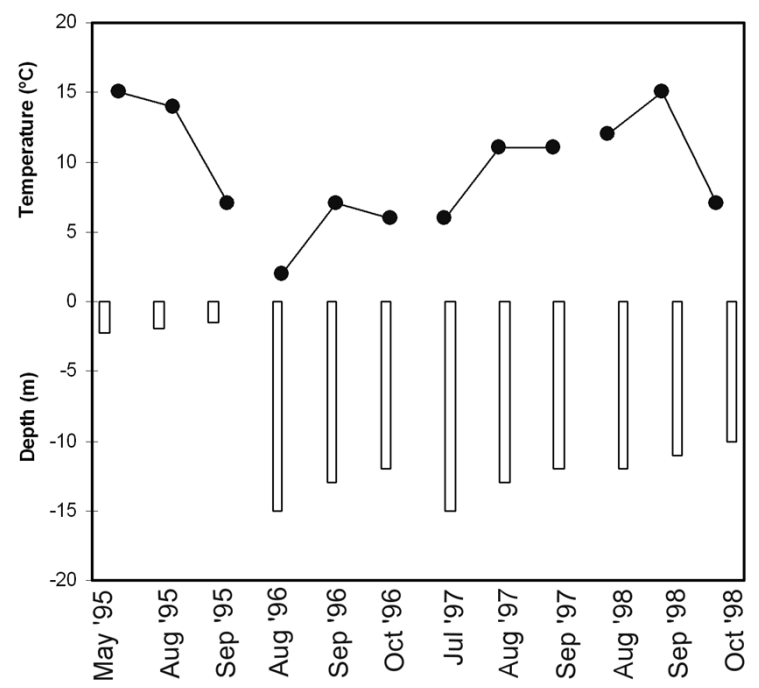

Fig. 1. Maximum depth (m) and temperature values $\left({ }^{\circ} \mathrm{C}\right)$ in La Caldera lake from 1995 to 1998. 
obtain suitable water for analysis from the epilithic fraction, a litre of supernatant was filtered several times in order to get a volume of water sufficiently transparent to realize the analyses. Nutrients were analysed on the same day as collection according to the following methods: chromatographic analyses were used for nitrate, phenol-hypochlorite for ammonium, the acid-molybdate process for SRP (APHA 1992; MOLAR 1999) and Mulling and Riley's technique (1955) for silicates (dissolved silica). Chemical analyses were done on the first two years of study: 1996 and 1997.

\subsection{Diatoms}

To study the diatom assemblages, aliquots of the sample were put into centrifuge tubes and 30\% hydrogen peroxide was added. The tubes were boiled during a period of 2-5 hours in order to oxidize organic matter, and then centrifuged to separate diatom frustules. A drop of the resulting solution was mounted upon a highrefraction medium (Naphrax). A total of 50 random microscopic fields (x100) were analysed or a minimum of 200 valves were counted. Diatom data are reported in terms of relative abundance. The Shannon and Wiener diversity index was used to calculate the degree of diversity.

\section{RESULTS}

\subsection{Population structure and dynamics}

The epilithic assemblage in the Laguna de La Caldera during the years 1996 to 1998 was made up of diatoms, cyanobacteria, green algae and chrysophytes, although in this first study we focused on the diatoms. During the ice-free period the diatom community was composed mainly of Fragilaria rumpens (Kütz) G.W.F. Carlson and Achnanthidium minutissimum (Kütz.) Czarn. (Fig. 2A). During the first year (1996) Fragilaria rumpens was the dominant species, accounting for 93.3\% of the assemblage in the mid-period sample. From then on until the end of the three-year study period, however, there was a clear decline in its relative population. Achnanthidium minutissimum, on the other hand, behaved in the opposite way. During the first year it represented scarcely $14 \%$ of the whole assemblage, whilst during the second year its presence rose to between $47 \%$ and $60 \%$, a presence which it maintained until the end.

Apart from these two species, which represent the major component of the community, the evolution of the rest of the species detected with any regularity throughout the study period are shown in figures $2 \mathrm{~B}$ and $2 \mathrm{C}$. Worth mentioning amongst these are Encyonema minutum (Hilse) Mann, Encyonopsis microcephala (Grun.) Krammer, Psammothidium helveticum (Hustedt) Bukhtiyarova \& Round and Navicula cryptocephala Kütz, which all followed a similar trend to that of $A$.
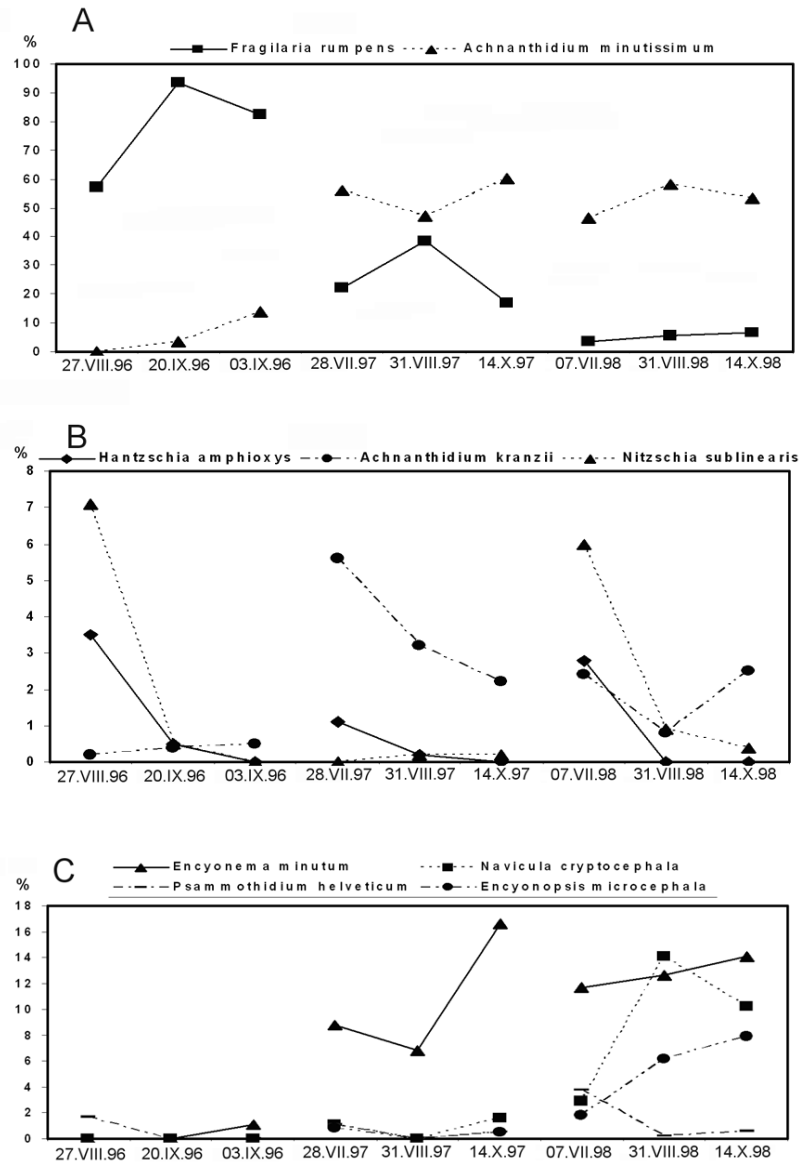

Fig. 2. Distribution and percentile representation of the principal diatom taxa. A: dominant taxa; $\mathbf{B}$ : minor taxa of continuous presence; $\mathbf{C}$ : minor taxa present at the end of the study period.

minutissimum, i.e. they showed scarce presence in 1996 but increased in 1997 and 1998. Also of note (Fig. 2C), although in lesser proportions than any of the above, are Nitzschia sublinearis Hustedt and Hantzschia amphioxys (Ehrenberg) Grunow, which followed a similar pattern to that of $F$. rumpens, showing a maximum presence in the first samples and thenceforth declining. Together with these was a small species of Achnanthidium, A. kranzii (Lange-Bertalot) Round \& Bukhtiyarova, the presence of which developed along the same lines as that of A. minutissimum.

The pioneering nature of $F$. rumpens can clearly be seen from live samples in which this species is found colonising small micaschist crystals (Fig. 3A). In contrast, live samples of communities in which A. minutissimum is the dominant species reveal the enormous biological diversity of the assemblage, with high proportions of cyanobacteria (Nostoc, Tolypothryx and Chamaesiphon, among others) and to a lesser extent green algae (Bulbochaete), upon which A. minutissimum grows epiphytically (Fig. 3B). 

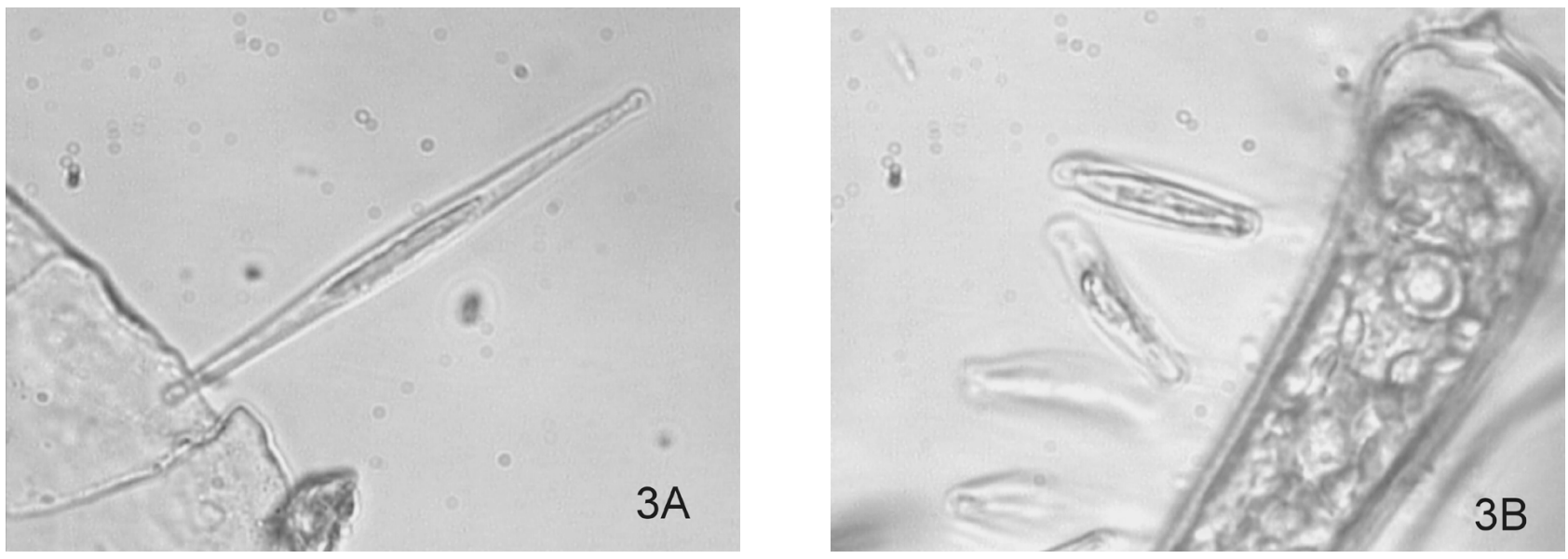

Fig. 3. Dominant diatom species in living samples. A: Fragilaria rumpens on micaschist crystals. B: Achnanthidium minutissimum on green algae Bulbochaete sp.

\subsubsection{Diversity index}

According to Shannon and Wiener's index (Fig. 4), the diversity values are always above 1.0, except for the two last samplings in 1996 (between 0.4 and 0.6), which coincided with the maximum abundance of $F$. rumpens and the almost complete absence of other taxa. After this the diversity index rose concomitantly with the development of the assemblage, reaching values of around 2.0. The first samples of each year show higher values than the following two, indicating that the greatest diversity each year occurs just when the lake becomes free of ice, which may be due to the development of diatoms from auxospores or other resistant forms that have survived the low temperatures of winter. Finally it should be noted the stabilization in the value of the diversity index between September and October.

\subsection{Environmental factors}

\subsubsection{Nutrients}

An analysis of the nutrient concentrations measured both at the rock-water interface and from the epilimnion (Fig. 5) reveals the different patterns of seasonal change

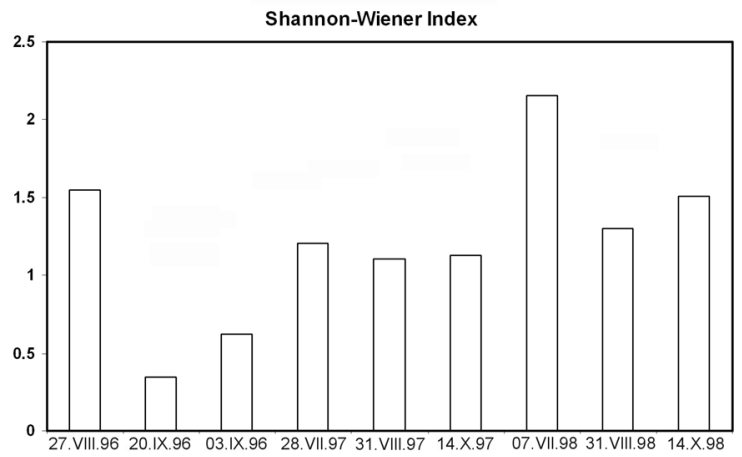

Fig. 4. Diversity values during the study period (Shannon and Wiener Index). which occurred during the study period. The rock-waterinterface data collected during the first year shows a variable pattern in most of the elements (nitrate, ammonia and silica) from the beginning to the end of the summer period. Phosphorus is the only nutrient showing a clear increasing trend during this summer. During the second year, however, the relative values remained fairly stable, concomitant with a general decrease in their concentration throughout the summer, except for ammonia, which increased somewhat. The chemistry of the epilimnetic samples in general terms followed a similar pattern to that of the rock-water interface.

\subsubsection{Nutrient ratios (DSi:SRP and DIN:SRP)}

The molar ratios between dissolved inorganic nitrogen (DIN), soluble reactive phosphorus (SRP) and dissolved silica (DSi) are lower in the epilithic than in the epilimnetic samples, indicating a greater presence of phosphorus at the lake's edge than in open water. The change in the DSi:SRP ratio follows a similar pattern in both environments during the first year. During the second year this tendency remains, although the strong seasonal drop in the epilimnion is noteworthy. The values of the DIN:SRP ratio are considerably lower in the epilithon during both years and also decline considerably during the summer season. They are more stable in the epilimnion, on the other hand, probably due to the decrease in nitrogen witnessed during the second year.

\section{DISCUSSION}

\subsection{The diatom assemblages}

The assemblages of the first summer were clearly different from those that developed during the following two years, both in terms of the epilithic populations and the chemical parameters of their environment. During the first summer of 1996 they were characterised by a predominance of Fragilaria rumpens, accompanied by 
Nitzschia sublinearis, Hantzschia amphioxis and Psammothidium helveticum, in an environment of very scarce diversity. The presence of these species coincided with very special environmental conditions in the Laguna de La Caldera. At the end of a long drought, 1996 was the first year in which the basin was resubmerged, together with recording one of the lowest temperatures measured in the lake (Morales et al. 1999). Thus Cremer et al. (2001) attributed the appearance of F. rumpens to a fall in the water temperature. In the light of the fact that from the second year onward this species began to be replaced by A. minutissimum, we believe that $F$. rumpens is more of a pioneer alga that colonises bare substrates that have remained emerged for several years. This taxon also appears in other lakes in the Sierra Nevada where the water level fluctuates (SánchezCastillo 1986; Linares-Cuesta 2003). The appearance of this species coincides with high concentrations of nutrients (Fig. 5) both in interstitial and open waters. F. rumpens is considered to be a species normally found in hyperoligotrophic-to-mesotrophic waters (Leclercq \& Fabri 1982; Cremer et al. 2001). The increase in nutrients in La Caldera kept it within the typical levels of oligotrophy of lakes in the Sierra Nevada (Morales et al. 1992), and in fact it would seem that short-term fluctuations in water level, rather than an increase in nutrients, often found in alpine environments, favour the successful development of Fragilaria (Lotter et al. 1999) compared to other more stable species.

During the second year the abundance of the two principal species had become reversed: the presence of F. rumpens had fallen markedly to $22 \%$ whilst that of $A$. minutissimum had risen to $56 \%$. Other species such as Encyonema minutum and a small species of Achnanthidium, A. kranzii, had also begun to appear. During the third year this trend continued with a further reduction in the presence of $F$. rumpens and a concomitant increase in A. minutissimum, together with other species which had hardly registered before, such as Encyonopsis microcephala and Navicula cryptocephala. This assemblage registered the highest diversity values (between 1.5 and 2.2) and can also be considered more stable than that of $F$. rumpens alone, and more typical of lakes with less fluctuation in their surface levels.

A. minutissimum is a species common to neutral or slightly alkaline water. Flower and co-workers (1986) found that it is abundant at $\mathrm{pH}$ values above 6 but gradually decreases from 6 to 5 , and practically disappears below 5, which fits our results perfectly, as during the 1998 sampling, when the presence of A. minutissimum was at its highest, the $\mathrm{pH}$ of the epilithon was between 6.6 and 7.2. This also agrees with the observations of van Dam et al. (1988), who maintain that the optimum $\mathrm{pH}$ for the growth of this species is around 6.8. Round (1990) recorded a clear dominance of this species in waters which had been neutralised by liming after a process of acidification, as has also been reported in the
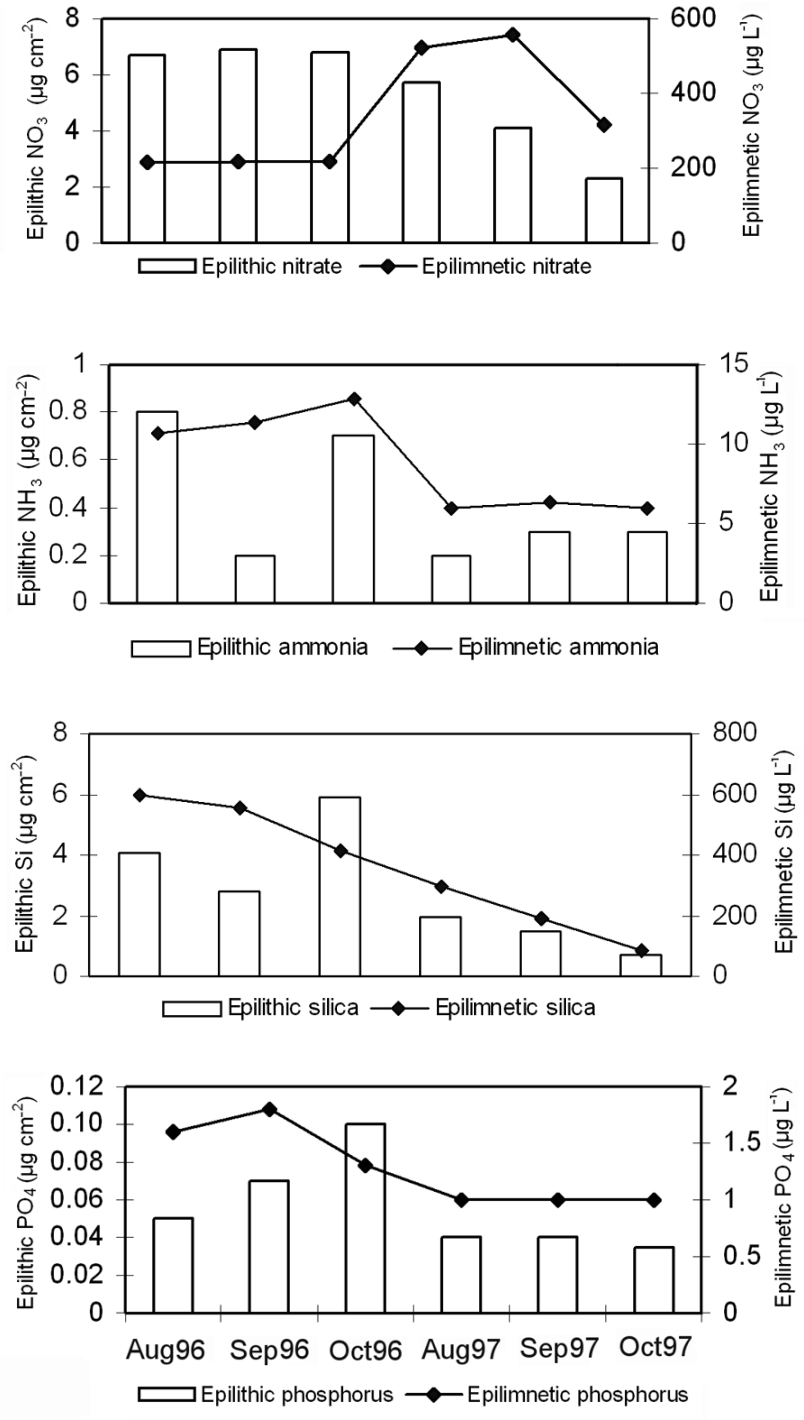

Fig. 5. Nutrient concentration in interstitial water from epilithic community and epilimnion between 1996 and 1997.

studies carried out by the MOLAR project (The Molar Water Chemistry Group 1999).

\subsection{Environmental parameters}

A clear difference can be seen between the values measured during the first summer (1996) and the following years, both in the epilithic and epilimnetic samples. To understand the higher values of the first year we must bear in mind that during 1996 the depth of water in the lake reached $15 \mathrm{~m}$ compared to the $1.5 \mathrm{~m}$ of the year before (Fig. 1). We may presume therefore that in 1995 the sediments and benthic communities which remained out of the water during the summer were considerably oxidised.

A comparison of the epilimnetic and rock-water interface nutrients of the lake show similar trends for 
ammonia, silica and phosphorus (Fig. 5), the dynamics of which can be put down to the lake's recovery from the extreme drought of the previous ten years; from 1996 onwards the whole basin was flooded, the nutrients were dissolved from mineralised organic matter and pervaded both the benthic and limnetic zones of the lake. Therefore, we can understand the overall decrease of the nutrients (all except for nitrate) between 1996 and 1997 at the rock-water interface as well as in the epilimnion.

The nitrates need more explaining, not only because their trend does not follow that of the rest of the nutrients but also because La Caldera contains the highest level of inorganic nitrogen in the whole of the Sierra Nevada (Morales Baquero et al. 1999). During 1996 the epilimnetic nitrate concentrations were quite low compared to the somewhat higher epilithic ones. In the following year, however, the epilimnetic values had surpassed the epilithic ones. Measurements taken from open water (Villar-Argaiz 1999) in 1996 show similar values to our data. Our study of the epilithic assemblage lead us to observe the presence of cyanobacteria in 1997 but not in 1996, when these organisms had not had time to develop to any great extent. The increase in nitrate values observed in interstitial waters during the summer of 1996 could be put down in part to the intense process of remineralisation of the organic materials which took place during the drought, and also to an absence of photosynthetic organisms which could have consumed some of the nitrates, as they probably did in 1997 (see presence of Bulbochaete in figure 3).

As far as the DIN:SRP and DSi:SRP ratios are concerned, clear differences appear in the epilimnetic and epilithic samples (Tab. 1). In 1996 the DSi:SRP values in the epilithon were between 55 and 131, which are considerably lower than the values of 300 obtained in cultures of Synedra filiformis by Kilham (1986), and 533 for the limnetic environment of $F$. rumpens in other lakes in the Sierra Nevada. We have also found values between 121 and 524 in our epilimnetic samples in this study. An analysis of this data together with the DIN:SRP ratio leads us to question the reliability of a generalised application of the concept of phosphorus limitation of primary production in continental aquatic systems. Our results suggest that phosphorus limitation is much more severe in the limnetic environment than it is in the epilithon (Tab. 1). In order to understand the obtained results, limnetic versus epilithic, (Fig. 5) we must consider the strong difference of units between both media (litres versus squared centimetres). Turner and co-workers (1994) maintain that phosphorus limitation is not so severe in systems with a gently sloping basin, as the remains of the organisms of these and other communities accumulate and break down in the littoral zone.

This lake presents a very heterogeneous littoral, a zone with a shallow slope, whereas other lakes show a strong inclination, though both cases have important irregularities that allow for the accumulation of organic matter. The decomposition of these remains would thus provide enough phosphorus for the growth of the organisms that make up the epilithic assemblages.

\section{ACKNOWLEDGMENTS}

Chemical analyses were funded by the European project Mountain Lake Research (MOLAR). Special acknowledgements to Dr. Isabel Reche and Dr. Manuel Villar. We thank our colleague A.L. Tate for the English text.

\section{REFERENCES}

A.P.H.A. 1992. Standard methods for the examination of water and wastewater. American Public Health Association. Washington.

Beyens, L. \& B. Van De Vijver. 2000. First contribution to the diatom flora of High Arctic Hopen Island (Svalbard). Nova Hedwigia, 70(3-4): 409-424.

Carrillo, P., I. Reche, P. Sánchez-Castillo \& L. Cruz-Pizarro. 1995. Direct and indirect effects of grazing on the phytoplankton seasonal succession in an oligotrophic lake. $J$. Plankton Res., 17: 1363-1379.

Cremer, H.B. \& B. Wagner, M. Melles \& H. Hubberten. 2001. The postglacial environmental development of Raffles, East Greenland: inferences from a 10.000 year diatom record. J. Paleolimnol., 26: 67-87.

Dixit, S.S., A.S. Dixit \& J.P. Smol. 1991. Multivariable envi-

Tab. 1. Inorganic nutrient ratios in rock-water interface and epilimnion in La Caldera lake between 1996 and 1997.

\begin{tabular}{lccccc}
\hline & \multicolumn{2}{c}{ DSi:SRP } & & \multicolumn{2}{c}{ DIN:SRP } \\
\cline { 2 - 3 } \cline { 5 - 6 } & Rock-water interf. & Epilimnion & & Rock-water interf. & Epilimnion \\
\hline $27-8-96$ & 131 & 524 & & 145 & 110 \\
$20-9-96$ & 55 & 446 & & 74 & 102 \\
$3-10-96$ & 77 & 445 & & 77 & 140 \\
$28-7-97$ & 70 & 423 & & 86 & 379 \\
$31-8-97$ & 51 & 268 & 65 & 402 \\
$14-10-97$ & 29 & 121 & & 235 \\
\hline
\end{tabular}


ronmental inferences based on diatom assemblages from Sudbury (Canada) lakes. Freshwat. Biol., 26: 251-266.

Dixit, S.S., B.F. Cumming, H.J.B. Birks, J.P. Smol, J.C. Kingston, A.J. Uutala, D.F. Charles \& K.E. Camburn. 1993. Diatom assemblages from Arondinack lakes (New York, USA) and the development of inference models for retrospective environmental assessment. J. Paleolimnol., 8: 27-47.

Douglas, M.S.V. \& J.P. Smol. 1995. Periphytic diatom assemblages from high arctic ponds. J. Phycol., 31(1): 60-69.

Flower, R.J., B. Rippey \& D.J. Tervet. 1986. Thirty-four Galloway Lochs: Bathymetry, water quality and surface sediment diatom assemblages. Working Paper 14, Palaeoecology Research Unit, Department of Geography, University College, London.

Jones, V.J. \& S. Juggins. 1995. The construction of diatom based chlorophyll-a transfer function and its application at three lakes on Signy Island (maritime Antarctic) subject to differing degrees of nutrient enrichment. Freshwat. Biol., 34: 433-445.

Kilham, S. 1986. Dynamics of Lake Michigan natural phytoplankton communities in continuous cultures along a Si:P loading gradient. Can. J. Fish. aquat. Sci., 43: 351-359.

Leclerq, L. \& R. Fabri. 1982. Flore et vegetation algales des eaux oligotrotrophes dû bassin de la Schwalm (Belgique, Province Liege). Bull. Soc. R. Bot. Belg., 115: 53-68.

Lim, D.S., C. Kwan \& M. Douglas. 2001. Periphytic diatom assemblages from Bathurst Island, Nunavut, Canadian High Artic: an examination of community relationships and habitats preferences. J. Phycol., 37: 379-392.

Linares-Cuesta, J.E. 2003. Las diatomeas bentónicas del parque nacional de Sierra Nevada. Estudio comparado con las colecciones del Herbario de la Universidad de Granada (GDA). Tesis Doctoral. Universidad de Granada

Loeb, S.L., J.E. Reuter \& C.R. Goldman. 1983. Littoral zone production of oligotrophic lakes. In: R.G. Wetzel (Ed.), Periphyton of freshwater ecosystems. W. Junk Publishers: 161-168.

Lotter, A.F., R. Pienitz \& R. Schmidt. 1999. Diatoms as indicators of environmental change near arctic and alpine treeline. In: Stoermer, E. \& J.P. Smol (Ed.), The diatoms: applications for the Environmental and Earth Sciences. Cambridge University Press.

Medina-Sánchez , J.M., M. Villar-Argaiz, P. Sánchez-Castillo, L. Cruz-Pizarro \& P. Carrillo. 1999. Structure changes in a planktonic food web: biotic and abiotic controls. $J$. Limnol., 58: 213-222.

Received: August 2007

Accepted: May 2008
Morales-Baquero, R., P. Carrillo, L. Cruz-Pizarro \& P. Sánchez-Castillo. 1992. Southernmost high mountain lakes in Europa (Sierra Nevada) as reference sites for pollution and climatic change monitoring. Limnetica, 8: 39-48.

Morales-Baquero, R., P. Carrillo, I. Reche \& P. SánchezCastillo. 1999. Nitrogen-phosphorus relationship in high mountain lakes: effects of the size of catchment basins. Can. J. Fish. aquat. Sci., 51: 1809-1817.

Molar, The MOLAR Water Chemistry Group (1999). The Molar project: atmospheric deposition and lake water chemistry. J. Limnol., 58: 88-106.

Mullin, J. \& J.P. Riley. 1955. The colorimetric determination of silicate with special reference to sea and natural waters. Anal. Chem. Acta, 12: 162-176.

Round, F.E. 1990. The effect of liming on the benthic diatom populations in three upland Welsh lakes. Diatom Res., 5(1): 129-140.

Sánchez-Castillo, P.M. 1986. Algas de las lagunas de alta montaña de Sierra Nevada (Granada, España). Acta Botánica Malacitana, 13: 21-52.

Sánchez-Castillo, P.M., L. Cruz-Pizarro \& P. Carrillo. 1989. Caracterización del fitoplancton de las lagunas de alta montaña de Sierra Nevada (Granada, Spain) en relación con las características fisico-químicas del medio. Limnetica, 5: 37-50.

Stoermer, E.F \& J.P. Smol. 2000. The diatoms: Applications for the environmentals and Earth Sciences. Cambridge University Press.

Turner, M.A., E.T. Howell, G.G. Robinson, P. Campbell, R.E. Hecky, \& E.U. Schindler. 1994. Roles of nutrients in controlling growth of epilithon in oligotrophic lakes of low alkalinity. Can. J. Fish. aquat. Sci., 51: 2784-2793.

Van Dam, H., V. Van Geel, A. Vanderwijk, J.F. Geelen, R. Vanderheiden, R. \& M.D. Dickman. 1988. Palaeolimnological and documented evidence for alkalization and acidification of two moorland pools (The Netherlands). Review of Paleobotany \& Palynology, 55: 273-316.

Villar-Argaiz, M. 1999. Redes tróficas pelágicas: una perspectiva estequiométrica. Tesis Doctoral. Universidad de Granada. Granada.

Wetzel, R.G. 1990. Land-water interfaces: metabolic and limnological regulators. Verh. int. Ver. Limnol., 24: 6-24.

Whitmore, T.J. 1989. Florida diatom assemblages as indicators of trophic state and pH. Limnol. Oceanogr., 34 (5): 882895. 